the creation of a department to act as an intermediary between the scientific branches of the universities and technical colleges and the various industries, for carrying out scientific and technical researches that may be of value to the latter, and the Union has issued an appeal to industries to submit their problems and difficulties to it for the purpose of having these investigated by competent scientific authorities whom the abovenamed department is in a position to select. It is rather disquieting to find that the German method of attacking the question is an individualistic one to the extent that it is the industries themselves and the scientific and technical institutions which propose to find the necessary funds and to provide the means of solving their own difficulties, whilst we in this country, who have hitherto been proud of our individualistic principles, which have ever formed the basis of Britain's industrial greatness, are content to sink our individualism and to ask a Government Department to solve our industrial problems for us.

The German Iron and Steel Institute has taken a prominent part in the extension of the research movement. This institute joined the above-mentioned Union of Technical Scientific Societies at an early stage, and took an active share in its formation; it has furthermore founded a research institution of its own for the investigation of problems connected with iron and steel manufacture. Here, again, it is characteristic of the quite modern trend of German methods that the iron and steel industry proposes to provide practically the whole of the important funds required for such an institution, whilst the town in which this is to be built will have to provide a suitable building site and a contribution to the cost of erecting the buildings. Although we in this country have not been unmindful of the need for applying scientific research to the numerous problems that arise in iron and steel manufacture, we have attempted nothing on the scale of this projected German institution to be devoted entirely to this need. For example, the Alloys Research Committee of the Institution of Mechanical Engineers had an excellent piece of work to its credit. Thanks to the munificence of $\mathrm{Mr}$. Andrew Carnegie, our own Iron and Steel Institute, too, has been enabled to assist and encourage research for the past seventeen years; but this has been done on quite different lines. The Carnegie Fund enables scholarships to be awarded, the holders conducting a specified research in the metallurgy of iron and steel at any suitable university, technical school, or works, the results being communicated to the Iron and Steel Institute, and in this way a great deal of useful and valuable work has been done. It is unquestionable that an institution equipped and maintained for such researches in any of our great metallurgical centres could do even better work than is possible to workers widely scattered, not provided with the best possible equipment, and each probably in ignorance of what the others are doing. It cannot be suggested that our iron and steel industry is less NO. 2533, VOL. IOI] capable of providing the requisite funds, and, seeing that every single important invention in iron and steel manufacture has emanated from this country, it cannot be supposed that British metallurgists are less capable of conducting such researches or of applying their results; there is therefore no reason whatever why we cannot do here what the Germans are proposing to do, and do it at least as efficiently.

The other movement, too, for a more intimate union and a closer co-operation amongst the leading technical societies, is one that deserves equally to be imitated in this country. The first step ought to be joint action amongst our technical societies, above all between those connected with the mining, metallurgical, and allied industries, the key industries of our national prosperity; they ought to have a joint building in which they could all be housed, forming a common meeting place for all, with suitable laboratories, and, in particular, one common library in which the whole of the world's technological literature could be found readily accessible to every student or inquirer. Such a library alone would save as much time and money, merely by avoiding the vast duplication of efforts that is now going on, as would give an adequate return upon its cost, not to mention the new vistas of study that it would open up. A building of this kind already exists in New York, where some of the most important of the technical and engineering societies are housed under one roof, to their very great mutual advantage. If we had such a building in London it might very beneficially shelter also the new Imperial-Bureau of Mineral Resources, which would become immensely more useful if it were thus in close and constant touch with the chief technical societies and through them with the industries themselves. The technical societies, on the other hand, would gain by being able to communicate directly with the Government Department with which they would be chiefly concerned, and couid work with it whilst at the same time preserving their independence, thus gaining the advantage of Government support without the risk of being strangled by administrative red-tape.

H. L.

\section{CONFERENCE OF UNIVERSITIES.}

$A N$ important conference which met at the Imperial Institute on May ro was attended by about seventy representatives of the universities of the United Kingdom and also by Mr. Joynt, representing New Zealand, Prof. Bragg, representing the universities of Australia, President Tory, representing the universities of Canada, and Prof. Gilbert Murray, Acting-Director for the Board of Education of Special Inquiries and Reports. Sir Donald Macalister was voted to the chair.

Matters arising out of a private and preliminary conference at the Foreign Office were considered. A committee was appointed to advise the Government with regard to representatives of British universities to take part in Mr. Balfour's Mission to the United States. The vice-chancellor or principal of each university, or a deputy appointed 
by him, together with the executive committee of the Universities Bureau, were appointed to consider any matters of common interest arising out of the proceedings of the conference or submitted to it by the Government.

The title of the degree to be obtainable by stuaents of the King's Dominions overseas or of foreign countries as the result of post-graduate work and research was discussed at considerable length, revealing a much higher degree of unanimity than seemed to be likely when the conference met a year agro.

It was recognised by the conterence that the question of the title of a degree and the conditions under which it could be obtained were of far greater import than the influence which the degree might have in attracting graduate students to the United Kingdom. It involves the whole question of the function of universities in the modern world. In our own country the tradition still lingers that a university is a place of post-school education, whereas in the modern world there is greater need for the provision of highly trained men and women capable not merely of absorbing knowledge, but also of increasing the common stock. This position was well defined by Sir Ernest Rutherford, whose speech may be quoted as an epitome of the views of the conference:-

It should be made clear that the new degree which many universities propose is an entire innovation. It will involve a full period of post-graduate training, introducing into Britain a system practically identical with that which obtains in America, and to a large extent in Canada also. It is of great importance that it should be adopted by the English-speaking world. In Britain it is likely to be a degree of very high standard, because we have the opportunity of building it on an honours basis. It is generally considered that the course should last for not less than two years, and this, I consider, is as it should be for a student who has already taken an honours degree, say in the first class, before he starts post-graduate work and investigation. If he shows promise and ability he will be able to take the M.A. in a year. We must also consider those who come to us from a distance, who will already in many cases have done a certain amount of research. It will be a real and very great departure in English education-the greatest revolution, in my opinion, of modern times. It is true that some universities have already attempted postgraduate training in a somewhat spasmodic manner. To carry out the scheme in its entirety will involve a much larger and more highly specialised staff and much more money for equipment.

\section{NOTES.}

WE deeply regret to announce that Sir Alexander Pedler,.F.R.S., died suddenly on Mondav, May I3, at sixty-eight years of age, while attending a committee meeting at the Ministry of Munitions. Sir Alexander was formerly Vice-Chancellor of the University of Calcutta and Director of Public Instruction for Bengal. He retired in 1906 , and since 1907 had been the honorary secretary of the British Science Guild, as well as an active member of many other public and scientific bodies.

WE learn with great pleasure that Oliver Heaviside has been elected an honorary fellow of the American Institute of Electrical Engineers. $\mathrm{He}$ is the fifth honorary fellow, the others being Marconi, Ferranti, Blondel, and C. E. L. Brown. Heaviside has often contributed to our columns on scientific theory and on educational matters. He holds very strong views about the mathematical teaching that used to be given in our schools, and has little patience with concentration upon its logic and philosophy. In his own books he does not spare the reader, but makes him master his own peculiar nomenclature and notation before he can learn those principles of electromagnetic theory which he has developed so successfully, and some of which are of great importance to practical engineers. His books would have a far wider vogue if he had conformed more to conventional methods, but the value of his - work would probably have suffered, and he would have lost much of the pleasure which he obviously felt in writing them. Standardisation has its uses, but it has also serious limitations. Many of us are grateful to Lodge, Perry, and Searle for explaining many of the good things in his books which we might otherwise have passed over. From the practical point of view Heaviside's most important discovery was the "distortionless" circuit for speech transmission and his suggestion of the use of inductance coils at intervals in long telephonic lines. This suggestion was taken up and developed by Pupin and other American electricians, and has been largely and most successfully utilised in many submarine telephone lines all over the world. We rejoice that our American confrères have done Oliver Heaviside honour; we thank them and offer to him our warmest congratulations.

THE Pereira medal of the Pharmaceutical Society of Great Britain has been awarded to Miss H. C. M. Winch.

LORD ROTHSCHILD has been elected an honorary member of the Entomological Society of Spain, of which we recently noted the foundation.

The Decimal Association informs us that the Federation of British Industries, by a unanimous resolution of the executive council, has now given its support to the Decimal Coinage Bill which is before the House of Lords.

Mr. W. B. Randall, of Waltham Cross, has generously provided funds for the establishment of a new research post at the Rothamsted Experimental Station, and the committee has appointed Mrs. D. J. Matthews (formerly Miss Isgrove) to occupy it. Mrs. Matthews will devote herself to the study of some of the problems connected with soil sterilisation as it is now being carried out in certain types of nurseries.

'IHE annual congress of the South-Eastern Union of Scientific Societies will be held at Burlington House on Maý 29-June I, and will follow the usual lines. The president will be Sir Daniel Morris, who will deliver his address on the evening of Wednesday, May 29, when his subject will be "A Chapter in the Geographical Distribution of Plants." On Thursday evening, May 30 , at 8 p.m., Sir Ronald Ross will open a discussion on mosquitoes in England.

THE death is announced, on May i2, of Dr. R. G. Hebb, consulting physician and physician pathologist to Westminster Hospital, lecturer on pathology at Westminster Hospital Medical School, reader in morbid anatomy at the University of London, and editor of the Journal of the Royal Microscopical Society.

We regret to record the death at Newcastle-uponTyne on May 7 of Sir William Haswell Stephenson, aged eighty-two years. Sir William joined the Tyne Improvement Commission in 1878 , and from 1900

NO. 2533, VOL. IOI] 